\title{
Effect of drought on oil, fatty acids and protein contents of groundnut ( Arachis hypogaea L.) seeds
}

\author{
S.L. Dwivedi ${ }^{*}$, S.N. Nigam, R.C. Nageswara Rao, U. Singh, K.V.S. Rao ${ }^{1}$ \\ International Crops Research Institute for the Semi-Arid Tropics (ICRISAT), ICRISAT Asia Center, Patancheru 502324, Andhra Pradesh, \\ India
}

Received 27 January 1996; revised 23 August 1996; accepted 23 August 1996

\begin{abstract}
The rainfed groundnut ( Arachis hypogaea L.) crop suffers from moisture stress of varying intensity at different growth stages. The effect of drought on oil, protein and fatty acid contents were studied in 12 genotypes that differed in seed quality traits. The genotypes were subjected to mid-season and the end-of-season drought in field experiments at ICRISAT Asia Center (IAC), Patancheru, India, conducted during the 1991/92 and 1992/93 postrainy (November-April) seasons. Mid-season drought was imposed between 40 and 80 days after sowing (DAS). The crop received normal irrigation, $50 \mathrm{~mm}$ at 10 day intervals, before and after the imposition of mid-season drought until harvest. Using the line-source sprinkler technique, end-of-season drought of varying intensity was imposed from 80 DAS until harvest. Mid-season drought had no significant effect on the content of oil, protein and fatty acids other than eicosenoic fatty acid. End-of-season drought significantly reduced total oil, and linoleic and behenic fatty acid content, and significantly increased total protein and stearic and oleic fatty acid content. However, genotype by treatment interactions were found. In ICGVs 88369, 88371, 88381, 88382 and 88403 , total oil content remained unaffected while oleic fatty acid content increased under end-of-season drought. These were identified as desirable parents for a breeding program to develop cultivars suitable for rainfed cultivation.
\end{abstract}

Keywords: Peanut; Seed quality; Mid-season drought; End-of-season drought; Groundnut

\section{Introduction}

Groundnut (Arachis hypogaea L.) is an important oilseed crop in the world. The use of groundnut as

\footnotetext{
${ }^{*}$ Corresponding author. Tel.: +91-40-596161; fax +91-40241239; e-mail: s.dwivedi@cgnet.com.

${ }^{1}$ Present address: National Academy of Agricultural Research Management (ICAR), Rajendranagar, 500030 Hyderabad, A.P., India.
}

food has gradually increased from the mid 1970's. Its consumption as food increased by $34 \%$ in the decade since 1970's and is expected to increase further (Fletcher et al., 1992).

Groundnut seeds contain $44-56 \%$ oil and $22-30 \%$ protein on a dry seed basis (Savage and Keenan, 1994). In addition, they are a good source of minerals (phosphorus, calcium, magnesium and potassium) and vitamins ( $\mathrm{E}, \mathrm{K}$ and $\mathrm{B}$ group). Besides physical (seed mass and shape, integrity of seed testae and 
blanching efficiency) and sensory (seed color, texture, flavor) factors, nutritional (oil and protein contents, fatty acid and amino acid composition) factors are important in the food trade. Oleic $(\mathrm{O})$ and linoleic (L) fatty acids together account for $75-80 \%$ of the total fatty acids in groundnut (Treadwell et al., 1983; Dwivedi et al., 1993a). The nutritional and storage qualities of groundnut depend on the relative proportion of saturated and unsaturated fatty acids in the oil. A high proportion of polyunsaturated fatty acid is desirable because it lowers plasma cholesterol and low-density lipoprotein content, which may reduce the risk of coronary heart disease and atherogenesis (Jackson et al., 1978). The iodine value (IV), which provides a measure of the degree of oil unsaturation and the $\mathrm{O} / \mathrm{L}$ ratio have been commonly used to predict shelf-life and measure the stability of the oil. $\mathrm{High} \mathrm{O} / \mathrm{L}$ ratio and low IV value generally indicate good stability and long shelf-life (Worthington et al., 1972; Young and Waller, 1972). Nutritional quality of the seed is strongly influenced by production location, cultivar and season, particularly soil moisture and temperature during crop growth and seed maturation (Young et al., 1972; Sanders et al., 1982; Dwivedi et al., 1993a) and seed size (Mozingo et al., 1988).

In many parts of the world, groundnut is grown under rainfed conditions. The crop often suffers from drought stress of varying intensity and duration. The adverse effect of drought on pod yield (14-88\% decrease) and seed grade (100-seed mass) of groundnut is well documented (Stansell et al., 1976; Pallas et a1., 1979; Nageswara Rao et al., 1985; Nageswara Rao et al., 1989). However, studies on the effect of drought on seed quality are limited, and often report conflicting results. Total oil content was not affected by early-season drought (Conkerton et al., 1989; Bhalani and Parameswaran, 1992), but declined (by up to $3 \%$ ) under mid-season (50-80 days after sowing (DAS) drought (Conkerton et al., 1989). For late-season drought (110-140 DAS), different studies have reported no effect (Conkerton et al., 1989; Musingo et al., 1989) and a decline (Bhalani and Parameswaran, 1992) in total oil content. No consistent effect on protein content have been documented due to drought stress at any particular growth period; nor was protein content in any specific genotype always reduced or increased by drought stress (Con- kerton et al., 1989). However, Musingo et al. (1989) reported that late-season (50 days before harvest) drought caused little change in total protein content of groundnut.

Fatty acid contents in a genotype are affected by drought stress and seed grade. 'Florunner' stressed for 30 days at seed maturation (80 DAS) had a higher percentage of palmitic and linoleic acids, lower percentage of stearic, oleic and eicosenoic acids, higher IV and alpha-tocopherol and lower $\mathrm{O} / \mathrm{L}$ ratio than nonstressed Florunner. A similar 30-day stress during the pre-flowering (20 DAS) and pod formation (50 DAS) increased behenic and lignoceric acids and decreased IV and gammatocopherol. While pre-flowering stress increased $\mathrm{O} / \mathrm{L}$ ratio, stress at pod formation increased alphatocopherol compared to stress at seed maturation. Regardless of timing of drought, with increasing seed grades, arachidic acid, behenic acid, lignoceric acid, eicosenoic acid, $\mathrm{O} / \mathrm{L}$ ratio and alpha-tocopherol decreased significantly (Hashim et al., 1993). However, Bhalani and Parameswaran (1992) did not find any major changes in the fatty acid composition, except for oleic acid, due to differential irrigation regimes in a summer irrigated crop. The oleic acid content increased in regimes where one irrigation was withheld each at flowering (50-65 DAS), pod development (90-105 DAS) and pod maturation (105-120 DAS) stage. The control in the experiment received eight irrigations at $10-15$ day intervals.

To breed for improved nutritional quality of groundnut, genetic resources with improved and stable nutritional quality are required. The present experiment studied the effect of mid-season and endof-season drought on oil and protein contents and fatty acid composition in 12 groundnut (Arachis hypogaea L.) genotypes.

\section{Material and methods}

Eight confectionery (large-seeded) genotypes, two drought-resistant genotypes, a popular Indian cultivar (JL 24) and an early-maturing germplasm line (Chico) were included for this study. The drought- resistant (ICGVs 86635 and 86707) and confectionery (ICGVs 
$88365,88369,88371,88381,88382,88391,88403$ and 88409) genotypes were developed at ICRISAT Asia Center (IAC), Patancheru, India. ICGV 86635, ICGV 88391, Chico and JL 24 belong to subsp fastigiata var. vulgaris and the other genotypes to subsp hypogaea var. hypogaea. These genotypes differ in branching pattern, pod yield $(0.72$ to $3.64 \mathrm{t}$ $\mathrm{ha}^{-1}$ ), meat content ( 610 to $700 \mathrm{~g} \mathrm{~kg}^{-1}$ pod), 100seed mass ( 27 to $95 \mathrm{~g}$ ), oil content ( 470 to $510 \mathrm{~g}$ $\mathrm{kg}^{-1}$ seed), protein content (200 to $270 \mathrm{~g} \mathrm{~kg}^{-1}$ seed) and $\mathrm{O} / \mathrm{L}$ ratio $(0.95$ to 1.97$)$.

Two experiments were conducted on an alfisol (clayey-skeltel, mixed, isohyperthermic family of Udic Rhodustalfs) field at IAC to simulate the effect of drought during the 1991/92 and 1992/93 postrainy (November-April) seasons. Experiment 1 (mid-season drought) and experiment 2 (end-of-season drought) were located on the same field adjacent to each other. For both experiments, a basal dose of single superphosphate of $250 \mathrm{~kg} \mathrm{ha}^{-1}$ was incorporated into the soil by broadcasting during land preparation. Seeds were treated with a mixture of Thiram ${ }^{(1)}$ and Captan ${ }^{\circledR}$ of $3 \mathrm{~g} \mathrm{~kg}^{-1}$ of seed and then sown on $1.2 \mathrm{~m}$ wide raised beds, separated by $0.3 \mathrm{~m}$ wide furrows. During both seasons, two sprays of Rogor ${ }^{\circledR}$ of $0.35 \mathrm{~kg}$ a.i. ha ${ }^{-1}$ were given to control thrips (Thrips palmi Karny). In 1991/92, Nuvacron ${ }^{\circledR}$ of $0.40 \mathrm{~kg}$ a.i. $\mathrm{ha}^{-1}$ was sprayed to control leafminer (Aproaerema modicella Deventer). All 12 genotypes were included in both experiments. In experiment 1 , the genotypes were sown in a randomized block design with three replications. The seeds were sown $10 \mathrm{~cm}$ apart in 4 rows separated at $30 \mathrm{~cm}$ intervals on a bed. The planting rows were parallel to the furrows. The plot consisted of 4 rows of $4 \mathrm{~m}$ length. In experiment 2 , the seeds were sown in rows perpendicular to furrows with $30 \mathrm{~cm}$ between rows and $10 \mathrm{~cm}$ between seeds in a row. Each genotype was sown on eight beds, each with two rows of $1.2 \mathrm{~m}$ length forming a plot. The plant density of 333000 $\mathrm{ha}^{-1}$ was maintained in both the experiments. Preemergence herbicide, Alachlor ${ }^{\circledR} @ 1.5 \mathrm{~kg} \mathrm{ha}^{-1}$, was sprayed soon after sowing and the field was irrigated with about $50 \mathrm{~mm}$ of water using overhead sprinklers. Subsequently, both experiments were uniformly irrigated at 10-day intervals (each irrigation with about $50 \mathrm{~mm}$ water) until the drought treatments were imposed. In experiment 1 , mid-season drought was imposed between 40 and 80 DAS, by withholding irrigation. From 80 DAS until harvest, the crop received regular irrigation $(50 \mathrm{~mm}$ at 10 -day interval) through overhead sprinklers. In experiment 2 , the crop was irrigated regularly until 80 DAS and end-of-season drought imposed from that stage until harvest. Line-source irrigation (Hanks et al., 1976) was used from 80 DAS to create eight intensities of end-of-season drought (described later). The main source line was laid perpendicular to the beds. The lateral lines with sprinkler heads ran along the beds. The sprinkler heads had dual nozzles of $3.17 \mathrm{~mm}$ and $3.97 \mathrm{~mm}$ aperture size with an output of about $40 \mathrm{~L} \mathrm{~min}{ }^{-1}$ when operated at $1.3 \mathrm{MPa}$. The sprinklers were operated during periods when wind velocity was minimal (less than $3 \mathrm{~km} \mathrm{~h}^{-1}$ ). This method of irrigation created a gradient of water application across the eight beds. For each irrigation, the amount of water applied to each bed was measured in all replications using catch-cans. The bed nearest the sprinkler head (first bed, B 1) received approximately $50 \mathrm{~mm}$ of water at each irrigation, providing an irrigated control treatment within each replication. The amount of irrigation decreased in a linear fashion as the distance of the bed from the sprinkler head increased.

The relative water deficit (WD) for each bed was estimated as

$\mathrm{WD}=100 \times(\mathrm{CPE}-\mathrm{TI} / \mathrm{CPE})$,

where CPE is the cumulative U.S. class A pan evaporation during the period of drought and TI is total irrigation applied during the period of drought.

End-of-season drought was imposed for 50 days during 1991/92 and for 68 days during 1992/93 postrainy seasons. During the drought period, 0.8 mm rain occurred at 136 DAS in 1991/92 and 18.0 $\mathrm{mm}$ rain at 112-113 DAS in 1992/93. This rainfall was taken into account in the WD calculations. Cumulative evaporation over the growing season was $985 \mathrm{~mm}$ in 1991/92 and $995 \mathrm{~mm}$ in 1992/93. Other weather parameters (averaged over the entire crop period) were as follows: solar radiation $18.2 \mathrm{MJ}$ $\mathrm{m}^{-2}$ day $^{-1}$ in $1991 / 92$ and $18.8 \mathrm{MJ} \mathrm{m}^{-2}$ day $^{-1}$ in $1992 / 93$; wind velocity $7.45 \mathrm{~km} \mathrm{~h}^{-1}$ in $1991 / 92$ and $6.6 \mathrm{~km} \mathrm{~h}^{-1}$ in $1992 / 93$; relative humidity $81.2 \%$ in $1991 / 92$ and $84.4 \%$ in $1992 / 93$ at $07.00 \mathrm{~h}$ and 
$29.7 \%$ in $1991 / 92$ and $34.0 \%$ in $1992 / 93$ at 14.00 h.

Bed

B 1 (irrigated control)

B 2

B 3

B 4

B 5

B 6

B 7

B 8 (bed farthest from the sprinkler head)

The quantity of irrigation applied to control plots (B 1) did not fully compensate for evaporation losses particularly during the latter part of the season. Although the irrigated control plots experienced 22\% water deficit in 1991/92 and $15 \%$ water deficit in $1992 / 93$, the crop showed no visual wilting symptoms in either season.

The average soil temperature over 2 seasons at $06.00 \mathrm{~h}$ recorded at $5 \mathrm{~cm}$ of soil depth by thermocouples for the period from 1 February until harvest ranged from 16 to $22^{\circ} \mathrm{C}$ in $\mathrm{B} 1$ (irrigated control), from 16 to $24^{\circ} \mathrm{C}$ in $\mathrm{B} 5$ (moderate water deficit) and from 16 to $26^{\circ} \mathrm{C}$ in $\mathrm{B} 8$ (maximum water deficit). The average temperature at $14.00 \mathrm{~h}$ ranged from 26 to $31^{\circ} \mathrm{C}$ in $\mathrm{B} 1$, from 26 to $36^{\circ} \mathrm{C}$ in $\mathrm{B} 5$ and from 26 to $41^{\circ} \mathrm{C}$ in $\mathrm{B} 8$.

Individual plots were harvested. After shelling, sound mature seeds were analysed for total oil, total protein and individual fatty acid contents. The samples from B 7 and B 8 were not analysed because of poor seed development due to extreme drought conditions.

Oil content was determined using nuclear magnetic resonance (Jambunathan et al., 1985). To estimate protein content, nitrogen concentration was determined using a Technicon autoanalyzer (Singh and Jambunathan, 1980). A factor of 5.46 was used to convert nitrogen into crude protein content (The United Nations University, 1980). The fatty acid methyl esters (FAME) of triglycerides were prepared (Hovis et al., 1979) and analysed to estimate individual fatty acid contents (Dwivedi et al., 1993a).
In the end-of-season drought experiment, WD values for the eight beds were as follows:

Relative water deficit (\%)

$\begin{array}{ll}1991 / 92 & 1992 / 93 \\ 22 & 15 \\ 30 & 20 \\ 40 & 27 \\ 52 & 36 \\ 64 & 52 \\ 78 & 68 \\ 90 & 82 \\ 96 & 92 \\ \mathrm{SE} \pm 1.5 & \mathrm{SE} \pm 2.4\end{array}$

Since the two experiments were located adjacent to each other in the same field both years, the B 1 plot in the end-of-season drought experiment was used as an irrigated control for the mid-season drought experiment. For each experiment, data over the two seasons were combined for analysis. Analyses of variance were performed using a mixed model where drought treatments (mid-season and end-ofseason) and seasons were treated as random and genotypes as fixed effects. Combined data from the irrigated control (B 1) and mid-season drought experiment were analysed in a randomised block design to evaluate the effect of mid-season drought on seed quality traits. The six treatments (B 1 to B 6) in the end-of-season drought experiment were analysed in a split plot design with intensities of water deficit as main plots and genotypes as subplots. The effect of end-of-season drought (relative water deficit) on oil, protein and fatty acid contents, averaged over genotypes and seasons, was estimated by regressing (b) various quality parameters against the intensity of water deficit.

\section{Results}

\subsection{Mid-season drought}

The results of variance analyses of total oil, total protein and fatty acid contents are presented in Table 1. Genotypic $(G)$ variation was highly significant for all the parameters studied, but the variation due to environment $(E)$ was evident only in eicosenoic 
acid, which is a minor fatty acid in groundnut. The $E \times G$ and season $(S) \times G$ interactions for total oil content and $E \times S \times G$ for behenic acid were significant. Compared with the irrigated control, the total oil content in two genotypes increased significantly under mid-season drought; Chico (from 457 to 480 $\pm 5.1 \mathrm{~g} \mathrm{~kg}^{-1}$ seed) and ICGV 88391 (from 459 to $476 \pm 5.1 \mathrm{~g} \mathrm{~kg}^{-1}$ seed).

\subsection{End-of-season drought}

The results of analyses of variance for oil, protein and fatty acid contents are presented in Table 2.

$G$ for all parameters was highly significant, as was the case in mid-season drought. Variation due to water deficit treatments $(E)$ was also highly significant for all parameters except palmitic and lignoceric acids. More interaction effects were significant under end-of-season drought than under mid-season drought.

The sensitivity of various parameters to increasing water deficit in the end-of-season drought experi- ment was measured by the linear regression coefficient $(b)$, which was significant for total oil, total protein and stearic, oleic, linoleic and behenic acids (Table 3). Compared to the irrigated treatment (B 1), total oil decreased and total protein content increased as the intensity of end-of-season drought increased. Among the fatty acids, stearic and oleic increased while linoleic and behenic decreased.

The genotypes responded differentially for all the parameters, except for protein content, to increasing end-of-season drought intensity (Table 4). Total protein content in all genotypes increased; the increase being highest in ICGV $86635\left(b=1.06{ }^{* *}\right)$. Endof-season drought intensity did not affect oil content in ICGVs 88369, 88371, 88381, 88382 and 88403. In the remaining seven genotypes, oil content was reduced; the reduction was greatest in ICGV 86635 $\left(b=-1.14^{* *}\right)$. A significant increase in stearic acid was observed in six genotypes, with the highest increase in ICGV $88381\left(b=0.23^{* *}\right)$. In Chico and JL 24, both oleic and linoleic acids remained unaffected. In ICGV 86635, oleic acid increased signifi-

Table 1

Analyses of variance of total oil, total protein and fatty acid contents of 12 groundnut genotypes grown under irrigated and mid-season stress environments, 1991/92 and 1992/93 postrainy seasons (mean square values)

\begin{tabular}{|c|c|c|c|c|c|c|}
\hline Source & d.f. & Total oil & Total protein & Palmitic & Stearic & Oleic \\
\hline Water deficit environment $(E)$ & 1 & 0.00 & 0.20 & 1.07 & 6.25 & 123.76 \\
\hline Season $(S)$ & 1 & 0.05 & 23.85 & 0.19 & 1.03 & 79.36 \\
\hline$E \times S$ & 1 & 5.52 & 21.62 & 0.23 & $0.81^{*}$ & $35.90^{*}$ \\
\hline $\operatorname{Rep} /(E$ and $S)$ & 8 & 2.00 & 4.82 & 0.17 & 0.15 & 3.4 \\
\hline Genotype $(G)$ & 11 & $17.72^{* *}$ & $25.59^{* *}$ & $18.41^{* *}$ & $5.44^{* *}$ & $265.72 * *$ \\
\hline$E \times G$ & 11 & $3.91^{*}$ & 2.46 & 0.53 & 0.08 & 5.07 \\
\hline$S \times G$ & 11 & $5.15^{* *}$ & 4.80 & 0.44 & 0.26 & 8.83 \\
\hline$E \times S \times G$ & 11 & 2.31 & 3.39 & 0.38 & 0.12 & 3.89 \\
\hline Pooled error & 88 & 1.65 & 2.34 & 0.29 & 0.17 & 4.74 \\
\hline \multirow[t]{2}{*}{$\mathrm{CV}(\%)$} & & 3 & 6 & 5 & 14 & 5 \\
\hline & & Linoleic & Arachidic & Eicosenoic & Behenic & Lignoceric \\
\hline Water deficit environment $(E)$ & 1 & 229.02 & 0.19 & $0.87^{* *}$ & 0.00 & 0.23 \\
\hline Season $(S)$ & 1 & 10.03 & 0.64 & $1.36 * *$ & 4.48 & $1.03^{* *}$ \\
\hline$E \times S$ & 1 & $13.57^{*}$ & $0.61^{*}$ & 0.12 & $0.93^{*}$ & 0.07 \\
\hline $\operatorname{Rep} /(E$ and $S)$ & 8 & 2.20 & 0.07 & 0.05 & 0.14 & 0.02 \\
\hline Genotype $(G)$ & 11 & $280.02^{* *}$ & $1.23 * *$ & $0.39^{* *}$ & $4.02 * *$ & $0.19^{* *}$ \\
\hline$E \times G$ & 11 & 5.60 & 0.03 & 0.02 & 0.09 & 0.01 \\
\hline$S \times G$ & 11 & 8.31 & 0.08 & 0.02 & 0.22 & 0.02 \\
\hline$E \times S \times G$ & 11 & 5.51 & 0.06 & 0.02 & $0.36^{* *}$ & 0.02 \\
\hline Pooled error & 88 & 5.30 & 0.04 & 0.01 & 0.09 & 0.01 \\
\hline $\mathrm{CV}(\%)$ & & 7 & 11 & 9 & 8 & 7 \\
\hline
\end{tabular}


Table 2

Analyses of variance of total oil, total protein and fatty acid contents of 12 groundnut genotypes grown under irrigation and end-of-season drought environments, 1991/92 and 1992/93 postrainy seasons (mean square values)

\begin{tabular}{|c|c|c|c|c|c|c|}
\hline Source & d.f. & Total oil & Total protein & Palmitic & Stearic & Oleic \\
\hline Replication & 2 & 3.26 & 1.29 & 1.47 & 0.00 & 1.48 \\
\hline Season $(S)$ & 1 & 216.47 & $513.9^{* *}$ & 0.00 & $12.37 * *$ & $118.34^{*}$ \\
\hline Rep/season & 2 & 11.85 & 4.36 & 0.68 & 0.02 & 3.78 \\
\hline Water deficit environment $(E)$ & 5 & $53.68^{* *}$ & $163.64^{* *}$ & 0.13 & $3.11 * *$ & $167.91^{* *}$ \\
\hline$S \times E$ & 5 & 6.28 & $9.29^{* *}$ & 0.12 & 0.24 & 5.73 \\
\hline Error & 20 & 5.47 & 1.14 & 0.13 & 0.17 & 2.43 \\
\hline Genotype $(G)$ & 11 & $172.88^{* *}$ & $89.47^{* *}$ & $53.30^{* *}$ & $19.42 * *$ & $919.38^{* *}$ \\
\hline$S \times G$ & 11 & $4.99^{* *}$ & 2.88 & $1.17^{* *}$ & $0.41^{* *}$ & 13.61 \\
\hline$E \times G$ & 55 & $5.13^{* *}$ & 1.25 & $0.25^{* *}$ & $0.23 * *$ & $5.61^{* *}$ \\
\hline$S \times E \times G$ & 55 & 3.01 & $1.77^{*}$ & 0.12 & 0.08 & 2.46 \\
\hline Error & 264 & 2.24 & 1.19 & 0.15 & 0.08 & 2.92 \\
\hline \multirow[t]{2}{*}{$\mathrm{CV}(\%)$} & & 3 & 4 & 4 & 10 & 4 \\
\hline & & Linoleic & Arachidic & Eicosenoic & Behenic & Lignoceric \\
\hline Replication & 2 & 3.15 & 0.24 & 0.26 & 0.72 & 0.05 \\
\hline Season $(S)$ & 1 & 12.10 & 6.50 & 1.16 & $14.30^{* *}$ & $2.07^{* *}$ \\
\hline Rep/season & 2 & 0.90 & 0.69 & 0.42 & 0.02 & 0.10 \\
\hline Water deficit environment $(E)$ & 5 & $150.98^{* *}$ & $0.08^{* *}$ & $0.08^{* *}$ & $4.55^{* *}$ & 0.03 \\
\hline$S \times E$ & 5 & 4.68 & 0.03 & 0.04 & $0.26^{* *}$ & $0.03 *$ \\
\hline Error & 20 & 2.08 & 0.01 & 0.02 & 0.05 & 0.01 \\
\hline Genotype ( $G$ ) & 11 & $899.54^{*}$ & $3.95^{* *}$ & $1.37^{* *}$ & $7.08^{* *}$ & $0.55^{* *}$ \\
\hline$S \times G$ & 11 & 9.72 & 0.05 & 0.09 & $0.15^{*}$ & $0.03{ }^{*}$ \\
\hline$E \times G$ & 55 & $4.2^{* *}$ & $0.02 * *$ & 0.01 & $0.16^{*}$ & 0.01 \\
\hline$S \times E \times G$ & 55 & 1.79 & 0.02 & 0.01 & $0.09^{* *}$ & 0.01 \\
\hline Error & 264 & 2.15 & 0.01 & 0.01 & 0.06 & 0.01 \\
\hline $\mathrm{CV}(\%)$ & & 5 & 6 & 8 & 7 & 6 \\
\hline
\end{tabular}

cantly but linoleic acid did not decrease. In all other genotypes, oleic acid increased and linoleic acid decreased. ICGV 88382 showed the highest increase $\left(b=1.12^{*}\right)$ in oleic acid and the highest decrease $\left(b=-1.03^{* *}\right)$ in linoleic acid. The decrease in behenic acid was significant in seven genotypes,

Table 3

Effect of end-of-season drought on total oil, total protein and fatty acid contents averaged over 12 genotypes and 2 seasons

\begin{tabular}{|c|c|c|c|c|c|c|c|c|}
\hline \multirow{2}{*}{$\begin{array}{l}\text { Parameter } \\
\left(\mathrm{g} \mathrm{kg}^{-1} \text { seed }\right)\end{array}$} & \multicolumn{6}{|c|}{ End of the season drought treatments } & \multirow[t]{2}{*}{$\operatorname{LSD}(1 \%)$} & \multirow{2}{*}{$\begin{array}{l}\text { Regression } \\
\text { coefficient }(b)\end{array}$} \\
\hline & B 1 & B 2 & B 3 & B 4 & B 5 & B 6 & & \\
\hline Oil & 483 & 476 & 474 & 468 & 465 & 459 & 11.1 & $-0.41^{* *}$ \\
\hline Protein & 246 & 242 & 260 & 266 & 277 & 285 & 5.1 & $0.72^{* *}$ \\
\hline Palmitic & 108 & 108 & 107 & 107 & 107 & 107 & 1.7 & -0.01 \\
\hline Stearic & 27 & 28 & 28 & 31 & 31 & 32 & 1.9 & $0.09^{* *}$ \\
\hline Oleic & 442 & 445 & 454 & 460 & 468 & 483 & 7.4 & $0.73^{* *}$ \\
\hline Linoleic & 338 & 334 & 328 & 321 & 313 & 299 & 6.8 & $-0.69^{* *}$ \\
\hline Arachidic & 18 & 18 & 18 & 19 & 19 & 19 & 0.6 & 0.01 \\
\hline Eicosenoic & 13 & 13 & 13 & 13 & 13 & 13 & 0.6 & -0.01 \\
\hline Behenic & 39 & 39 & 37 & 35 & 34 & 33 & 1.0 & $-0.12^{* *}$ \\
\hline Lignoceric & 15 & 15 & 15 & 15 & 15 & 16 & 0.5 & 0.01 \\
\hline
\end{tabular}


Table 4

Genotypic response (linear regression coefficients, $b$ ) to end-of-season drought for total oil, total protein and fatty acid contents averaged over 2 seasons

\begin{tabular}{|c|c|c|c|c|c|c|}
\hline Genotype & Total oil & Total protein & Stearic & Oleic & Linoleic & Behenic \\
\hline Chico & $-0.96^{* *}$ & $0.81^{* *}$ & -0.03 & 0.13 & -0.17 & -0.00 \\
\hline JL 24 & $-0.81^{* *}$ & $0.59^{* *}$ & 0.04 & 0.03 & -0.18 & -0.05 \\
\hline ICGV 86635 & $-1.14^{* *}$ & $1.06^{* *}$ & $0.05^{* *}$ & $0.73^{* *}$ & -0.75 & $-0.09^{* *}$ \\
\hline ICGV 86707 & $-0.21^{* *}$ & $0.68^{* *}$ & 0.03 & $0.56^{* *}$ & $-0.53^{* *}$ & $-0.12^{* *}$ \\
\hline ICGV 88365 & $-0.38^{* *}$ & $0.69 * *$ & $0.10^{*}$ & $0.78^{* *}$ & $-0.73^{*}$ & -0.14 \\
\hline ICGV 88369 & -0.06 & $0.83^{* *}$ & 0.10 & $0.87^{* *}$ & $-0.75^{* *}$ & $-0.18^{* *}$ \\
\hline ICGV 88371 & -0.01 & $0.78^{* *}$ & $0.22 * *$ & $0.95^{* *}$ & $-0.93 * *$ & $-0.11^{* *}$ \\
\hline ICGV 88381 & 0.12 & $0.45^{*}$ & $0.23^{* *}$ & $1.02^{* *}$ & $-0.97 * *$ & $-0.17^{* *}$ \\
\hline ICGV 88382 & -0.19 & $0.78^{* *}$ & $0.15^{* *}$ & $1.12 * *$ & $-1.03^{* *}$ & $-0.17^{* *}$ \\
\hline ICGV 88391 & $-0.69^{* *}$ & $0.66 * *$ & -0.01 & $0.66^{* *}$ & $-0.55^{* *}$ & -0.05 \\
\hline ICGV 88403 & -0.19 & $0.68 * *$ & $0.14^{*}$ & $0.85 * *$ & $-0.81^{* *}$ & $0.13^{* *}$ \\
\hline ICGV 88409 & $-0.39^{* *}$ & $0.66^{* *}$ & 0.13 & $1.07^{* *}$ & $-0.96^{*}$ & $-0.21^{* *}$ \\
\hline $\operatorname{LSD}(1 \%)$ & 0.159 & 0.078 & 0.036 & 0.165 & 0.143 & 0.031 \\
\hline
\end{tabular}

highest in ICGV $88409\left(b=-0.21^{* *}\right)$. ICGV 88403 , on the other hand, showed a significant increase in behenic acid.

\section{Discussion}

\subsection{Oil and protein concentration}

The chemical composition of groundnut seed is influenced, among other factors, by its stage of maturity (Pickett, 1950; Young et al., 1972; Sanders, 1980). The present study therefore included only sound mature seeds to eliminate maturity-related differences in seed chemical composition. Total oil and total protein were not affected by mid-season drought, but end-of-season drought reduced oil and increased protein. This increase or decrease was progressive, corresponding to the intensity of water deficit. Differences in oil content became significant only under moderate to intense water deficit. In contrast, differences in protein became significant even at relatively low levels of moisture deficit (Table 3). Significant negative correlation $(r=-0.364$ to -0.822$)$ between total oil and total protein was observed (Tai and Young, 1975; Dwivedi et al., 1990). Holley and Hammons (1968) observed an increase in total oil and a decrease in total protein in wet years (nonstressed). Our results, however, are in disagreement with previous reports that late-season drought had little or no effect on total oil and total protein content (Musingo et al., 1989; Conkerton et al., 1989), or that mid-season drought reduced total oil content (Conkerton et al., 1989; Bhalani and Parameswaran, 1992). This could be due to the differences in genotypes and in the timing and intensity of drought in these studies. Further, growing conditions and crop management practices (foliar diseases control) also influence total oil, total protein and fatty acids in groundnut (Nagaraj and Chauhan, 1987; Dwivedi et al., 1993a; Dwivedi et al., 1993b). In the present study, genotypes $(G)$ interacted with season $(S)$ and end-of-season water deficit intensities $(E)$ for total oil. The $S \times E \times G$ interaction was significant for total protein.

\subsection{Fatty acid composition}

Fatty acids are synthesised by consecutive desaturation from stearic $\left(\mathrm{C}_{18}: 0\right)$ to oleic $\left(\mathrm{C}_{18}: 1\right)$ to linoleic $\left(\mathrm{C}_{18}: 2\right)$ fatty acid (Harwood, 1988). In the present study, mid-season drought had no significant effect on the major fatty acids. Stearic and oleic acids increased while linoleic and behenic acids decreased under end-of-season drought. The increase or decrease was progressive with increasing water deficit. Differences in oleic, linoleic and behenic acids became significant at a low level of moisture deficit; differences in stearic acid became significant at higher deficits (Table 3). These results differ from 
those of Hashim et al. (1993), who reported an increase in palmitic and linoleic acids and a decrease in stearic, oleic and eicosenoic acids when Florunner was stressed for 30 days at maturation. When a similar stress was imposed at the pre-flowering and pod formation periods, they observed an increase in behenic and lignoceric acids. These differences between the two studies could be ascribed to the larger number of genotypes in the present study and to significant $S \times G, E \times G$ and $S \times E \times G$ interactions noted for some of these acids.

High temperature $\left(27-33^{\circ} \mathrm{C}\right)$ during seed development is reported to decrease linoleic acid in several oilseed crops including groundnut (Holaday and Pearson, 1974; Harris et al., 1978; Wolf et al., 1982; Green, 1986; Golombek et al., 1995). The decrease is attributed to the effect of temperature on the activity of desaturase enzyme that converts oleic to linoleic acid. The changes in total oil and total protein contents and in fatty acid composition in the present study were probably due to the combined effect of water deficits and high temperatures during the seed-filling period with the end-of-season drought treatment. As the relative degree of water deficit increased, so did the soil temperature.

Total oil in ICGVs $88369,88371,88381,88382$ and 88403, oleic acid in Chico and JL 24 and linoleic acid in Chico, JL 24, and ICGV 86635 remained unaffected by end-of-season drought. Among genotypes in which oil was not influenced, oleic acid increased and linoleic acid decreased in ICGVs 88369,88382 and 88403 . These genotypes would be good parents in a breeding program to develop cultivars for rainfed conditions, because their oil content remains unaffected but oleic acid is increased by drought, thus improving the oil shelf-life and quality.

\section{Conclusion}

Mid-season drought did not affect the chemical composition (except for eicosenoic fatty acid) of groundnut seed in any significant manner. End-ofseason drought significantly affected the chemical composition of groundnut seed. Whereas total oil and linoleic and behenic acids decreased, total protein and stearic and oleic acids increased due to end-of-season drought. This increase or decrease was progressive and associated with the increasing degree of water deficit.

\section{References}

Bhalani, G.K. and Parameswaran, M., 1992. Influence of differential irrigation on kernel lipid profile in groundnut. Plant Physiol. Biochem., 19: 11-14.

Conkerton, E.J., Ross, L.F., Daigle, D.J., Kvien, C.S. and McCombs, C., 1989. The effect of drought stress on peanut seed composition. II. Oil, protein and minerals. Oleagineux, 44: 593-599.

Dwivedi, S.L., Jambunathan, R., Nigam, S.N., Raghunath, K., Shankar, K. Ravi and Nagabhushanam, G.V.S., 1990. Relationship of seed mass to oil and protein contents in peanut (Arachis hypogaea L.). Peanut Sci., 17: 48-52.

Dwivedi, S.L., Nigam, S.N., Jambunathan, R., Sahrawat, K.L., Nagabhushanam, G.V.S. and Raghunath, K., 1993a. Effects of genotypes and environments on oil content and oil quality parameters and their correlations in peanut (Arachis hypogaea L.). Peanut Sci., 20: 84-89.

Dwivedi, S.L., Nigam, S.N., Subrahmanyam, P., Jambunathan, R., Nagabhushanam, G.V.S., Reddy, P.M., Raghunath, K. and McDonald. D., 1993b. Effect of foliar diseases control by Chlorothalonil on pod yield and quality characteristics of confectionery groundnuts (Arachis hypogaea L.). J. Sci. Food Agric., 63: 265-271.

Fletcher, S.M., Zhang, P. and Carley, D.H., 1992. Groundnuts: Production, utilization and trade in 1980's. In: S.N. Nigam (Editor), Groundnut: A Global Perspective, Proc, of an Int. Workshop. ICRISAT Center, Patancheru, pp. 17-32.

Golombek, S.D., Sridhar, R. and Singh, U., 1995. Effect of soil temperature on the seed composition of three spanish cultivars of groundnut (Arachis hypogaea L.). J. Agric. Food Chem., 43: 2067-2070.

Green, A.G., 1986. Effect of temperature during seed maturation on the oil composition of low-linoleic genotypes of flax. Crop Sci., 26: 961-965.

Hanks, R.J., Keller, J., Rasmussen, V.P. and Wilson, G.D., 1976. Line source sprinkler for continuous variable irrigation crop production studies. Soil Sci. Soc. Am. J., 40: 426-429.

Harwood, J.L., 1988. Fatty acid metabolism. In: W.R. Briggs, R.L. Jones and V. Walbot (Editors), Ann. Rev. Plant Physiol. Plant Mol. Biol. Annual Reviews, Palo Alto, CA, 39: 101-138.

Harris, H.C., McWilliam, J.R. and Mason, W.K., 1978. Influence of temperature on oil content and composition of sunflower seed. Aust. J. Agric. Res., 29: 1203-1212.

Hashim, I.B., Koehler, P.E., Eitenmiller, R.R. and Kvien, C.K., 1993. Fatty acid composition and tocopherol content of drought stressed Florunner peanuts. Peanut Sci., 20: 21-24.

Holaday, C.E. and Pearson, J.L., 1974. Effect of genotype and production area on the fatty acid composition, total oil and total protein in peanuts. J. Food Sci., 39: 1206-1209.

Holley, K.T. and Hammons, R.O., 1968. Strain and seasonal 
effects on peanut characteristics. Res. Bull. No. 32, Georgia Agri. Exp. Sta., Tifton, GA, pp 5-27.

Hovis, A.R., Young, C.T and Kuhn, C.W., 1979. Effect of two strains of peanut mottle virus on fatty acids, amino acids and protein of six peanut lines. Peanut Sci., 6: 88-92.

Jackson, R.L., Taunton, O.D., Morrisett, J.D. and Gotto, Jr., A.M., 1978. The role of dietary polyunsaturated fat in lowering blood cholesterol in man. Critical Res., 42: 447-453.

Jambunathan, R., Raju, S.M. and Barde, P.S., 1985. Analysis of oil content of groundnuts by Nuclear Magnetic Resonance Spectrometry. J. Sci. Food Agric., 36: 162-166.

Mozingo, R.W., Coffelt, T.A. and Wynne, J.C., 1988. Market grade effects on fatty acid composition of five peanut cultivars. Agron. J., 80: 73-75.

Musingo, M.N., Basha, S.M., Sanders, T.H., Cole, R.J. and Blankenship, P.D., 1989. Effect of drought and temperature stress on peanut (Arachis hypogaea L.) seed composition. J. Plant Physiol., 134: 710-715.

Nagaraj, G. and Chauhan, S., 1987. Seasonal variation in the oil quality of groundnut. Indian J. Agric. Sci., 57: 522-524.

Nageswara Rao, R.C., Singh, S., Sivakumar, M.V.K., Srivastava, K.L. and Williams, J.H., 1985. Effect of water deficit at different growth phases of peanut. I. Yield responses. Agron. J., 77: 782-786.

Nageswara Rao, R.C., Williams, J.H. and Singh, M., 1989. Genotypic sensitivity to drought and yield potential of peanut. Agron. J., 81: 887-893.

Pallas, Jr., J.E., Stansell, J.R. and Koske, T.J., 1979. Effects of drought on Florunner peanuts. Agron. J., 71: 853-858.

Pickett, T.A., 1950. Composition of developing peanut seed. Plant Physiol., 25: 210-224.

Sanders, T.H., 1980. Fatty acid composition of lipid classes in oils from peanuts differing in variety and maturity. J. Am. Oil Chem. Soc., 57: 12-15

Sanders, T.H., Lansden, J.A., Greene, R.L., Drexler, J.S. and Williams, E.J., 1982. Oil characteristics of peanut fruit separated by nondestructive maturity classification method. Peanut Sci., 9: 20-23.
Savage, G.P. and Keenan, J.I., 1994. The composition and nutritive value of groundnut kernels. In: J. Smart (Editor), The Groundnut Crop: A Scientific Basis for Improvement. Chapman and Hall, London, pp. 173-213.

Singh, U. and Jambunathan, R., 1980. Evaluation of rapid methods for the estimation of protein in Chickpea (Cicer arietinum L.). J. Sci. Food Agric., 31: 247-254.

Stansell, J.R., Shepard, J.L., Pallas, Jr., J.E., Bruce, R.R., Minton, N.A., Bell, D.K. and Morgan, L.W., 1976. Peanut responses to soil water variables in the Southeast. Peanut Sci., 3: 44-48.

Tai, Y.P. and Young, C.T., 1975. Genetic studies of peanut proteins and oils. J. Am. Oil Chem. Soc., 52: 377-385.

The United Nations University, 1980. Analytical methods for the determination of nitrogen and amino acids in foods. In: P.L. Pellett and V.R. Young (Editors), Nutritional Evaluation of Protein Foods. A report of a working group sponsored by the International Union of Nutritional Sciences and the United Nations University World Hunger Programme. The United Nation University, Japan.

Treadwell, K., Young, C.T. and Wynne, J.C., 1983. Evaluation of fatty acid content of forty peanut cultivars. Oleagineux, 38: 381-385.

Wolf, R.B., Cavins, J.F., Kleiman, R. and Black, L.T., 1982. Effect of temperature on soybean seed constituents: Oil, protein, moisture, fatty acids, amino acids. J. Am. Oil Chem. Soc., 59: 230-232.

Worthington, R.E., Hammons, R.O. and Allison, J.R., 1972. Varietal differences and seasonal effects on fatty acid composition and stability of oil from 82 peanut genotypes. J. Agric. Food Chem., 20: 727-730.

Young, C.T. and Waller, G.R., 1972. Rapid oleic/linoleic microanalytical procedure for peanuts. J. Agric. Food Chem., 20: 1116-1118.

Young, C.T., Mason, M.E., Matlock, R.S. and Waller, G.R., 1972. Effect of maturity on the fatty acid composition of eight varieties of peanut grown at Perkins, Oklahoma in 1968. J. Am. Oil Chem. Soc., 49: 314-317. 